\title{
THE "BAUERNMISSION" AND THE IRONIES OF COLONIALISM: THE RELIGIO-CULTURAL LEGACY OF THE “BAUERNSIEDLUNG” PHILIPPI
}

\author{
Lizette Rabe \\ Department of Journalism, Stellenbosch University 7600
}

\section{Die "Bauernmission" en ironieë van die geskiedenis: die religio-kulturele erflating van die "Bauernsiedling" Philippi}

Die Duitse immigrante wat die drie "golwe" Duitsers gevorm het wat hulle in Suid-Afrika by Philippi in die Wes-Kaap in die negentiende eeu gevestig het, en hulle nakomelinge, het nie net tot die Wes-Kaap se agri-welstand bygedra deur die groeiende bevolking van vars produkte te voorsien nie, maar ook tot die diversiteit van die streek. Die aankoms in die Wes-Kaap van spesifiek die laaste twee "golwe" Duitse immigrante was tegelyk die gevolg van die Hermannsburgse Bauernmission (Boeresending) en die immigrasieprojekte van die Britse koloniale regering wat spesifiek Duitsers gewerf het om die Wes- en Oos-Kaap te bevolk. Die artikel bespreek die geskiedenis van die gevolglike Duitse Philippi-boerderygemeenskap 'n tipiese "Bauernsiedlung" - en die ironie van hulle religio-kulturele erflating en 'n nuwe generasie (im)migrante na die Wes-Kaap. Vertalings in Engels van die Duitse aanhalings word in voetnotas gegee.

Sleutelwoorde: agri/kultuur, Duitse immigrante, godsdiens, Hermannsburgse Sending, Philippi, Wes-Kaap

The German immigrants who formed the three "waves" of Germans to settle at Philippi in the Western Cape (South Africa) in the $19^{\text {th }}$ century, and their descendants, contributed not only to the agricultural well-being of the Western Cape by providing the growing population with fresh produce, but also to the diversity of the region with their German cultural heritage. The arrival in the Western Cape of specifically the last two "waves" of German immigrants was both the result of the Hermannsburg "Bauernmission" - "agricultural missionary society" - as well as a specific immigration drive by the British colonial government to recruit specifically Germans to populate various areas of the Western and Eastern Cape colonies, which coincided. This article discusses the history of the resultant Philippi German farming community - a typical 
"Bauernsiedlung" - and the irony of their religio-cultural legacy and a new generation of (im)migrants to the Western Cape. Translations of the German quotations are provided as footnotes.

Key words: agri/culture, German immigrants, Hermannsburg Missionary Society, Philippi, religion, Western Cape.

\section{Introduction}

The Philippi horticultural area, which today covers a surface of about 8 square kilometres and which provides the Western Cape with a significant percentage of fresh produce, as well as two congregations and a lively "German" community, form the last remains of what used to be an agricultural area which was more than triple the size of the remnant, as well as three thriving congregations and three schools.

Descendants of German immigrants to the Western Cape, specifically to what had then been called Claremont Flats and Wynberg Flats, since the end of the 1850s to 1883 , today comprise the community at Philippi Flats, the agricultural section of the larger geographical area of the Cape Flats, which specialises in the cultivation of vegetables for the bigger Cape metropolis.

Those descendants who still today belong to the Evangelical Lutheran Church, are mostly members of the two remaining Lutheran churches, namely the Philippi Evangelical Lutheran Church (also known as the Zionskirche) and the St Johanniskirche in Wynberg. These two churches established a "parish agreement" in July 2007 to ensure the survival of the Wynberg congregation, according to which the pastor of the Philippi congregation will also minister the Wynberg congregation.

\section{Background}

Members of the community are mostly the descendants of German settlers who came to the Western Cape over a period of 25 years from 1858 to 1883 in three "waves". This emigration from Europe was part of the "Völkerewanderung" (migration of the nations), the mighty socio-cultural phenomenon of the nineteenth century when between 1820 and 1890 an estimated 5 million Germans from the various German regions migrated to parts of the "New World."

E.L.G. Schnell, For men must work (Grahamstown, 1954), p. 159. 
Those who migrated to the southern tip of Africa, and who ended up on the Cape Flats, were the "Godeffroy Settlers", 2 representing the First Wave, with the Second Wave arriving from 1877 to 1878 , and the Third Wave in 1883. These last two "waves" were mostly so-called "Heidjer" - peasants from the Lüneburger Heide - who, as devoted Lutheran Christians, came to the Cape under the influence of the Hermannsburg Missionary Society.

This descriptive article focuses on the interface between this Völkerewanderung, the "Heidjer" as zealous proponents of the Hermannsburg "Bauernmission", and the British Colonial Government and its endeavours to populate the Western Cape with more Europeans of agricultural background, resulting in a twist of irony through the fact that one of their religious centres is now being utilised for the benefit of new "migrants" to the Cape.

\section{The Hermannsburg Missionary Society}

This society also became known as the "Bauernmission", or the agricultural missionary society, as the founder of the society recruited sons from farms in the surrounding Lüneburger Heide to become missionaries. As these farmers' sons lacked "academic" education, the missionary society was given the somewhat derogatory nickname of "Bauernmission". ${ }^{3}$

The founder of the missionary society, Ludwig Harms (1808-1865), was a minister's son who grew up as one of ten children in the Lüneburger Heide. ${ }^{4}$ As "Erweckungsprediger" - conversionist preacher - he established a huge following among the "Heidjer".

Harms himself was a fascinating person, who at first was not interested at all in theology and only studied it to please his father. In a letter to his brother ${ }^{5}$ he wrote that he decided to interrogate the whole world of knowledge, and immersed himself in natural sciences, biology, astronomy, philosophy, philology, theology and languages.

According to one source he spoke Latin as if it were his mother tongue. $\mathrm{He}$ was so acquainted with Greek and Hebrew that he could write down in one what was

L. Rabe, 'n Kultuurhistoriese studie van die Duitse nedersetting Philippi op die Kaapse Vlakte (“A Cultural Historical Study of the German settlement Philippi on the Cape Flats"), (Unpublished doctoral dissertation, University of Stellenbosch, 1994).

3 Die Nataler Deutschen, www.geocities.com/heartland/Meadows/7589/natal_de.html?200922, 200903-22.

4 F.W. Bautz, 1990. Harms, Ludwig (Louis). www.bautz.de/bbbkl/h/harms_1.shtml, 2009-03-22.

5 F.W. Bautz, 1990. Harms, Ludwig (Louis). www.bautz.de/bbbkl/h/harms_l.shtml, 2009-03-22. 
said in the other. He learned Italian to read Danté in the original; Spanish, to read Cervantes; Modern Greek to compare it with Ancient Greek; Sanskrit, to be able to understand the ancient writings of India; "French and English went without saying". But: "his heart remained empty". One night, according to him, God revealed himself to him - and the area of the Lüneburger Heide proved fertile ground for his message. ${ }^{6}$ His following among the devout Philippi immigrants is illustrated by the presence of a framed etch which today hangs in the Philippi Settler Museum. ${ }^{7}$ Similar etches could be found in several Philippi homes, as well as "Gebetbücher" - prayer books published by the Hermannsburg Missionary Society. This researcher also remembers, as a child in the 1960s, the constant references that were made to Ludwig/Louis Harms in the conversations of grown-ups.

The ideology behind Harms' specific missionary society was that newly converted Africans would not only need religion as "food for the soul", but also certain farming practices and skills as "food for the body". The Hermannsburg missionaries and missionary farmers would provide both.

Harms initially wanted to send missionaries to East Africa, but could not land there because the sultan at the time did not allow the Christians entry through Zanzibar. They then settled in Port Natal and worked among the Zulu. Over the years several missionary stations were established, spreading also to the then Zuid-Afrikaansche Republiek. ${ }^{9}$

Although the immigrants to the Western Cape did not come as missionaries or established missionary stations, they were part of the zealous following of Harms, and brought with them the specific Hermannsburg Lutheran missionary zeal, as did the immigrants to the then Natal and Transvaal, where there are also still remaining communities with strong German cultural values.

\section{Philippi: Historical Context}

The Philippi horticultural area lies approximately 30 kilometres from Cape Town. At its core origin can be found descendants of German Lutheran - Hermannsburg "Bauernmission" - immigrants from especially 1878 (the "second" wave) and $1883^{10}$

\footnotetext{
F.W. Bautz, 1990. Harms, Ludwig (Louis). ww.bautz.de/bbbkl/h/harms_1.shtml, 2009-03-22.

Etch: Ludwig Harms. "5 Mai 1808-14 November 1865. Verlag der Missionshaus in Hermannsburg."

8 There are several such "Gebetbücher" in the Philippi Settler Museum.

9 F.W. Bautz, 1990. Harms, Ludwig (Louis). www.bautz.de/bbbkl/h/harms_1.shtml, 2009-03.22.

10 L. Rabe, 'n Kultuurhistoriese studie van die Duitse nedersetting Philippi op die Kaapse Vlakte, 1994.
} 
(the third wave), who, together with those individuals who formed the first wave (from 1858 onwards), formed the Philippi community.

During this same period when the Völkerewanderung took place and the Hermannsburg Missionary Society established its specific version of a missionary society amongst devout farming families in the Lüneburger Heide, namely the latter half of the nineteenth century, the British Colonial Government at the Cape recruited German immigrants to populate the then desolate Cape Flats. The reason behind the Colonial Government's recruitment was twofold: they wanted more European settlers to strengthen the white population at the Cape, and also to provide the Cape with much needed fresh produce. ${ }^{11}$

At this same time, in Germany's Lüneburger Heide area, poor farmers were inspired to seek a new future for themselves, and at the same time "bring light to the dark continent" from within a strict Lutheran confession.

Harms wrote: "Wir Lutheraner haben das reinste und unverfälschte Bekenntnis" 12 - he did not even tolerate contact with Roman Catholics or Reformed Christians. The Bauernmission's followers were informed by his strict credo with regard to Africa and the spreading of the gospel:

Wir wollen den Heiden die lutherische Kirche bringen; denn man kann nichts bringen, als was man hat. Da wir der lutherischen Kirche Glieder sind, so wollen und können wir den Heiden natürlich keine andere Kirche bringen als die lutherische, deren Glieder wir sind. Und das auch deshalb, weil wir in der lutherischen Kirche das Wort Gottes in reiner, unverfälschter Lehre haben und in unsere Kirche Taufe und Abendmahl rein und unverfälscht nach Jesu Einsetzung verwaltet werden. ${ }^{13}$

In this climate, the British Colonial Government found willing emigrants to "Africa".

The British government's recruitment drive was inspired by the progress of the individual "free" Germans who initially came as indentured labourers - the "first

11 Die ersten Anfänge in der Vlakte, in W.J.L. Blumer (ed), Pflanzgarten im Dünensand. (Metropolitan Press, Wynberg, 1959), pp. 12-13.

12 Translation: "We Lutherans have the purest and unadulterated confession". F.W. Bautz, 1990. Harms, Ludwig (Louis). www.bautz.de/bbbkl/h/harms_1.shtml, 2009-03.22.

13 Translation: We want to bring the heathens the Lutheran Church; one cannot bring something that one does not have. As we are members of the Lutheran Church, we of course cannot bring the heathens any other church than the Lutheran. And then also, because in the Lutheran Church, we have the purest doctrine, and that in our church baptism and communion are used in the purest form according to Christ's induction. 
wave" of Philippi immigrants - to farms in the Cape's farming districts, especially the so-called "Swartland". After their contracts have expired (from the late 1850s to the 1870s), and they have saved enough money, they resettled on the "edge" of the Cape Flats where they started to cultivate vegetables. ${ }^{14}$

The German settlers to the Eastern Cape (the founders of towns with names such as Berlin, Stutterheim and Potsdam) also played a part in the settlement of the Western Cape. The success of these settlers inspired the Cape Government to do the same in the Western Cape with similar German stock. Apparently one colonial officer said that if the Germans could transform "a stone desert [the Eastern Cape] into a paradise", why not also a "sand desert"? 15

The First Wave immigrants settled on the "edge" of the Cape Flats because a German Lutheran church was already founded in Wynberg in 1861, after Swedish brewer Letterstät brought about thirty Swedes to the Newlands area. ${ }^{16}$

The Colonial Government came to the conclusion that if the Germans could cultivate vegetables on such sandy soil, other Germans will be able to do the same on the Flats proper. Minister John X. Merriman particularly wanted to populate the Western Cape $^{17}$ and focused especially on the area that lay between Table Mountain and the mountains of Stellenbosch and Strand. Minister Merriman wanted to make this area the source of production for Cape Town's much needed fresh produce. ${ }^{18}$ Certain parts of the Cape Flats, which was not populated since the arrival of the first European settlers in 1652, were consequently surveyed by the colonial government's surveyor-general with a view to settling the German immigrants. ${ }^{19}$

A recruitment project was subsequently launched in Germany's sandy Lüneburger Heide, where, unbeknown to the British Colonial Government, "ready" immigrants were in a certain sense awaiting them.

14 L. Rabe, 'n Kultuurhistoriese studie van die Duitse nedersetting Philippi op die Kaapse Vlakte, 1994.

15 W.H.C. Hellberg, Duitse Immigrasie na Wes-Kaapland ("German Immigration to the Western Cape") in W.J.L. Blumer (ed), Pflanzgarten im Dünensand, 1959, p. 16.

16 W.H.C. Hellberg, Die Deutschen Evangelisch-Lutherischen Kirchengemeinden im Westen des Kaplands (D.Phil thesis, University of Stellenbosch, 1957), p. 150.

17 W.J.L. Blumer (ed), Pflanzgarten im Dünensand, 1959, p. 13.

18 Original: [...]beide richteten ihre Augenmerk vor allem auf das Flachland, die Vlakte, die sich zwischen dem Tafelgebirge und den Bergen von Stellenbosch und Strand ausbreitet. Minister Merriman wollte die Vlakte zur Produktionsquelle des von Kapstadt benötigten Gemüses machen [.]

19 "Die ersten Anfänge in der Vlakte", in W.J.L. Blumer (ed), Pflanzgarten im Dünensand, 1959, p. 13. National Archives, Cape Town: Immigration Agent Cape (Document collection 4/3/3), Public Works Department (Document collection 1/68), House of Assembly (4/8); Office of the Surveyor-General, Cape Town: maps of the Philippi Flats settler area. 
What the immigrants did not know, was that the area intended for their settlement was uninhabitable due to various factors. ${ }^{20}$ One source gave this vivid description: ${ }^{21}$

Weder Weg noch Steg fuhr durch dieses Gebiet. Man sah keinen Baum noch Strauch. 2Ausser einer kümmerlichen Heideart wuchs nur noch ein kleines Gestrüpp. Im Januar und Februar, zur Zeit der Sommerhitze, war die ganze Vlakte eine Sand- und Staubwüste; im Juli und August dagegen, während der Winterregen, ein grosser See und Morast. Ungehindert konnte man aus der Vlakte bis nach Claremont und Wynberg hineinsehen. Der Boden war unbearbeitet und gänzlich unfruchtbar. Die im Sommer vorherrschenden Südostwinde trieben den losen Sand überall vor sich her. ${ }^{22}$

Schnell described the area as "practically useless," ${ }^{23}$ although this "weite, öde Sandund Heidefläche"24 (wide, barren sand and heath flats) were so beautiful in spring that it conjured up the following comparison: ${ }^{25}$

... im Frühjahr [war sie] übersät mit einem Teppich der schönsten und zartesten Blumen. Feierlich ruhig wie die Welt am Schöpfungstage, so lag sie da. ${ }^{26}$

The immigrants overcame hardships of various nature, and formed, as it was described in the 1930s, "eine einzigartige geschlossene Siedlung" (a uniquely closed settlement"). ${ }^{27}$

As an indication of the conservative nature of these immigrants who, still, after a couple of generations, upheld the strict Hermannsburg version of the Lutheran religion, can be seen in the 1930 description of Steinhoff ${ }^{28}$ : a settlement

20 L. Rabe, 'n Kultuurhistoriese studie van die Duitse nedersetting Philippi op die Kaapse Vlakte, 1994, pp. 13-14.

21 W.J.L. Blumer (ed), Pflanzgarten im Dünensand, p. 13.

22 Translation: Not a road, nor a lane, led through this area. You could not see a tree or shrub. Except for a pitiful type of heather, only brushwood grew. In January and February, in the time of the summer heat, the Flats were one sand and dust desert; in July and August, on the other hand, because of the winter rain, a huge vlei and marsh. Without interruption one could see right to Claremont and Wynberg. The soil was uncultivated and sterile. The trade winds of summer blew the loose sand all over.

23 E.L.G. Schnell, For men must work, p. 224.

24 H. Ludewig, Geschichte der Deutschen Evangelisch-Lutherischen St. Johannis-Gemeinde zu Wynberg bei Kapstadt (Braunschweig, 1911), p. 28.

25 H. Ludewig, Geschichte der Deutschen Evangelisch-Lutherischen St. Johannis-Gemeinde, p. 28.

26 Translated: ... in spring they were covered with a carpet of the most beautiful and loveliest flowers. It looked as festive as the world during its creation ...

27 I. Steinhoff, 700 Deutsche die niemals in Deutschland waren, Hamburger Illustrierte, 1938-02-07.

28 I. Steinhoff, 700 Deutsche die niemals in Deutschland waren, Hamburger Illustrierte, 1938-02-07. 
die sich durch vier Generationen erhalten hat, getreu den Sitten und Bräuchen ihrer Vorfahren, findet man an der Südspitze Afrikas. ${ }^{29}$

Steinhoff ends the article:

Es ist erschütternd, an der Südspitze Afrikas diese alten, markanten Bauernköpfe zu sehen, wie aus Holz geschnitten, - und flachsblonden Kinder, die ebensogut in Pommern, Holstein order Hannover auf der Dorfstrasse spielen könnten. ${ }^{30}$

Since the 1950s, in other words after, and as a result of, the Second World War period, the community as a whole developed into a multilingual community as a result of intercultural marriages with Afrikaans or English-speaking partners. However, after all these years, German, Lutheran traditions dominated, still a manifestation of the stronghold of Harms and his narrow, conservative version of Lutheranism. ${ }^{31}$

\section{Philippi: Geographical Context}

Philippi is situated on the south western part of the vast geographical area known as the Cape Flats. This same Cape Flats has become a political term since the 1960s as a result of the Nationalist Government's apartheid policy, according to which parts of the original German settler farms were expropriated. This is the other side of the coin of forced expropriation which still needs to be told, as the German descendants and their property rights were not respected by the Afrikaner Nationalists.

With neighbours belonging to a low socio-economical class in the newly established townships now literally across the road from the remaining agricultural area, the result was that hitherto unknown socio-political problems such as theft of crops and general crime were experienced by the German farming community.

Up to the arrival of the German immigrants to the Western Cape in the $19^{\text {th }}$ century, however, the geographical area of the Cape Flats was to a great extent

29 Translation: to find a community that remained true to its origin and its traditions on the southernmost tip of Africa.

30 Translation: It is distressing to find, on the southernmost tip of Africa, such old, striking faces, as if chiseled out of wood - and flax blonde children who could as much have played on the village streets in Pommern, Holstein or Hannover.

31 L. Rabe, 'n Kultuurhistoriese studie van die Duitse nedersetting Philippi op die Kaapse Vlakte, 1994.

32 L. Rabe, 'n Kultuurhistoriese studie van die Duitse nedersetting Philippi op die Kaapse Vlakte, 1994, p. 9 . 
uninhabited..$^{32}$ It is interesting to note that geographical studies of the area ${ }^{33}$ indicated that the Cape Flats had been a sea strait, with the Peninsula Mountain Range an island.

With South Africa's historiography lacking focus in certain areas, it could up to now not be established whether this area had been inhabited by the indigenous Khoikhoi people. One can conclude, however, that, as a result of the lack of natural shelters and trees, nor sufficient grazing for their cattle, it would not have been used as a stand for the pastoral nomads. It can be accepted, though, that they certainly trekked over the Flats, as implements of the Khoikhoi, sea fossils and grinding stones as well as skeletons, for example, were found during sand-mining excavations. ${ }^{34}$

In summary: to a great extent the Cape Flats was uninhabited before the arrival of the first German immigrants, as it was seen as an inhospitable semi-desert. It was this area that the Cape Colonial Government thought fit for German settlement.

The Cape Flats were described as a "flat, even terrain of sand" that is marked by "vlei" areas (seasonal lakes). On these even flats there are smaller sand dunes in certain parts, and in many areas the water table is above ground during the rainy season. ${ }^{35}$

According to several sources it was uninhabitable due to various factors:

- sandy, infertile soil;

- sandstorms in summer;

- marshes and lakes in winter;

- no infrastructure such as roads due to the thick,

- shifting sand, and

- a total lack of water in summer. ${ }^{36}$

\section{The first years}

The immigrants was already a close-knit community when they arrived, with strong ties among themselves, some dating back generations, as many had existing family and friendship bonds in the villages of Northern Germany from where they were

33 H. Joubert, Die verstedeliking van die Kaapse Vlakte ("The urbanisation of the Cape Flats"), (Unpublished doctoral dissertation, University of Stellenbosch, 1956); M.S. Taljaard, A glimpse of South Africa (Stellenbosch, 1949).

34 Die Burger, 1950-06-05. n.p.

35 H. Joubert, Die verstedeliking van die Kaapse Vlakte, 1956, p. 27.

36 L. Rabe, 'n Kultuurhistoriese studie van die Duitse nedersetting Philippi op die Kaapse Vlakte, 1994, pp. 13-14. 
recruited. These bonds were cemented through the extreme hardships they endured on the Cape Flats, arriving with nothing but their "hands and their [Lutheran] Bible", as it was said. According to one descendant, she still remembered as a child hearing her grandparents refer to how the emigrants were "deceived" in Germany, being shown photographs of the leafy Constantia area and not of the desolate Flats. ${ }^{37}$

Being of peasant stock, and especially as followers of Harms for whom material possessions were not important, the immigrants did not have many possessions, nor did they bring significant possessions with them. They therefore literally started out with nothing but an allotted piece of (barren) land which had to be paid for over a period of ten years, and a tent as their sole shelter.

One newspaper report from 1883 stated that they were not, "as other immigrants had been, provided with any draught animals and other means of carrying on their industry". ${ }^{38}$ There was no infrastructure in the area in which the immigrants settled. They encountered a vast area of sand - in summer a desert, in winter a marshland. The report reads:

The German families settled on the Wynberg and Claremont Flats, amongst sand-hills about five miles from a hard road and a railway station, deserve the commiseration and assistance of the public. Most of the immigrants, brought out here under misrepresentations, stayed only a few days on their allotments, and perceiving the trap they had fallen into, packed up their scanty chattels, came to Wynberg, and sought and found employment. Several families however [...] have managed to live so far [...] It is a crying shame to treat honest hardworking people in this cruel manner, and the Government should be severely taken to task in reference to this matter when Parliament meets. ${ }^{39}$

This was the land they had to cultivate, and not only make a living from, but which had to provide them with the "new future" that they had dreamt of as peasants when they left their own country - and provide the Western Cape with fresh produce.

These hardships led to a well-known expression among the immigrants and their descendants according to which "the first generation earned death, the second hardship, and only the third started to prosper" ("Die erste Generation erntete das Tod, die zweite das Not und die dritte das Brot"). ${ }^{40}$

\footnotetext{
Personal interviews: Ida (Idi) Bode, b Schultz, and Frieda (Fidi) Schultz, 1988.

Article in The Cape Times, 1933-02-27, n.p.

Article in The Wynberg Times and South African Agriculturist, Simon's Town, Suburban and Western Province Advertiser, 1883, reprinted in the Wynberg and Plumstead News, 1988-01-13, n.p.

40 Author's own experience.
} 
The only "service" the Cape government had prepared for the arrival of the settlers was to survey the properties. ${ }^{41}$ "The surveyors marked the areas with border posts. The moving sand, however, covered these posts. One had to dig before one could find them." ${ }^{42}$ No access roads had been made to the area, nor were roads provided for in the area. ${ }^{43}$ The Dutch ridiculed the Germans: ${ }^{44}$ "In winter you will drown in water, and in summer you will die of thirst." ${ }^{45}$

There was literally nothing with which the German immigrants could begin their new lives. As one historian recorded: "hier in der Vlakte standen sie vor einem völligen Nichts" (here in the Flats they stood before a total nothingness). ${ }^{46}$ The realities were described as follows: ${ }^{47}$

Ohne Geld, ohne Vieh, ohne die einfachsten landwirtschäftlichen Geräte, als einziges Kapital ein Paar derbe Fäuste und ein mutiges Herz... Es war wohl niemand unter den Auswanderern, der sich von seiner unbekanntes Zukunft so viel versprach, wie es ihre Anwerber taten. Sie [the agents] wussten alle, dass es hier ein unbewohntes, vielleicht unfruchtbares Land zu bearbeiten, aufzubauen galt. Was die Bauern aber dort am Kap erwartet hat, muss alle Befürchtungen weit übertroffen haben. ${ }^{48}$

The immigrants lived in tents until they could erect better structures (made from bulrush and clay, the only material available). Men sought employment in town or the southern suburbs, while the women and children tried to cultivate the sand. On weekends the men returned with their earnings of $2 / 6$ to 3 shillings, and did their bit to bring the efforts "noch möglich vorwärts" (contributed to their efforts). ${ }^{49}$ Schnell wrote:

41 W.H.C. Hellberg, Von den deutschen Siedlern im Kapland, p. 93.

42 Original: "Die Landmesser hatten Grenzbaken in den Boden getrieben. Der bewegliche Sand hatte aber diese Grenzbaken verdeckt. Man musste graben, ehe man sie finden konnte."

43 L. Rabe, 'n Kultuurhistoriese studie van die Duitse nedersetting Philippi op die Kaapse Vlakte 1994, p. 41.

${ }_{44}$ H. Ludewig, Geschichte der Deutschen Evangelisch-Lutherischen St. Johannis-Gemeinde, p. 28.

45 Original: In de winter zal jullie verzuipen in water, en in de zomer verrekken van dorst.

46 W.J.L. Blumer (ed), Pflanzgarten im Dünensand, p. 13.

47 H. Bruckschen, Aus der Heide in die Vlakte, in W. Blumer (red), Pflanzgarten im Dünensand, p. 38 .

48 Translation: Without money, without livestock, without the simplest tools, as only capital a pair of hard fists and a brave heart... There was probably no one among the immigrants who heard so many promises about their unknown future as did they from their recruiters. They [the agents] all knew that it concerned an uninhabited, maybe infertile land, which they were supposed to cultivate. What the farmers found at the Cape, however, even surpassed all expectations.

49 H. Ludewig, Geschichte der Deutschen Evangelisch-Lutherischen St. Johannis-Gemeinde, . 29. 
At first the work was difficult and disappointing, their initial attempts failed lamentably. All their experience in Germany availed them nothing, here they had to begin learning afresh. ${ }^{50}$

\section{The agricultural beginnings}

One can only imagine what the first years must have been like. With no aid, no funding, no understanding of the climate in the southern hemisphere, the immigrants had to start on sandy soil with nothing. There are many anecdotes telling of the hardships and endurance which became part of the cultural and spiritual "diet" of following generations of descendants and which engendered a legendary work ethic among the descendants of the original immigrants.

To name a few:

- How the whole family would work when it is full moon to extend the work day through the night

- How the women, who would walk the $30 \mathrm{~km}$ to Cape Town laden with what little they could produce which was not consumed, would pick up horse manure on their way back and carry it in their empty baskets back to their allotment to fertilise the sandy soil

- How language and cultural differences and British supremacy on the side of the colonialists, contributed to their hardship.

One such example (of many) is the story of a hunting club at the Cape which, accustomed to having the Cape Flats as their playground, trampled the wearisomely tilled fields of the immigrants, lashed a settler when he protested, and, when he fell to the ground, further humiliated him. When the settler took the incident to court, the magistrate turned out to be one of the hunters who participated in the assault, and subsequently dismissed the case. ${ }^{51}$

Another is the story ${ }^{52}$ of the immigrant who built himself a small cart as his next achievement after a couple of harvests in order to cart his produce into town. Once there, he was arrested and his cart hacked to pieces. His misdemeanour? $\mathrm{He}$ did not have a licence. He could not understand the English officer nor the English court proceedings. In hindsight, the heavy handedness of the police was of course

\footnotetext{
$50 \quad$ E.L.G. Schnell, For men must work, p. 225.

51 W.H.C. Hellberg, Duitse Immigrasie na Wes-Kaapland, 1959, p. 18.

52 W.H.C. Hellberg, Duitse Immigrasie na Wes-Kaapland, 1959.
} 
typical of a hegemonic society. To add to the misery, those who succeeded to produce enough to be able to sell their small harvest in town, of course could also afford the licence - now that they knew of its existence. ${ }^{53}$

In den ersten Jahren haben die Ansiedler viel Arbeit umsonst getan; ein teures Lehrgeld haben sie zahlen müssen [...] Man muss sie bewundern, dass sie nach vielen Misserfolgen immer noch einmal von neuem zu Spaten und Hacke gegriffen haben. ${ }^{54}$

Merriman was convinced that the moving sands due to wind could be controlled by trees and shrubs in order to cultivate the soil. For this, he announced a competition in the Government Gazette in May 1877 for the best plantation of the first 50 acres, or if this were not possible, the best 25 acres, or, if this were not possible, the best 12 acres. $^{55}$

The immigrants, although ridiculed by the Cape Dutch who by then knew the agricultural shortcomings of the Flats, were not put off. One of the first years' biggest breakthroughs came when they realised there is a wealth of water below the surface, and how to harness that. They dug wells and, although still laborious work, at least they could water their small fields with bucket by bucket of fresh water.

The saying of the three generations held absolute truth. With each generation they improved their circumstances, and farming practices naturally improved as their own prosperity improved together with technology.

Harms was also influenced by Karl Marx, and communistic practices were part of the Bauernmission's ideology, and part of its success. Standing together the farmers could achieve much more than as individuals. The Philippi farmers also practiced these communistic values by, e.g., pooling together to import a Friesian bull to improve their livestock, and imported quality seed potatoes to improve their potato harvests.

Their sheer perseverance, graphically described in the following, ${ }^{56}$ became legendary amongst their descendants (the animosity against the British colonial masters who saw the suffering after they were "dumped" on the desolate Flats, were simultaneously also engendered in the next generations):

53 H. Ludewig, Geschichte der Deutschen Evangelisch-Lutherischen St. Johannis-Gemeinde, p. 29.

54 Translation: In the first years the settlers did many things for no gain; it was a hard lesson they had to learn [...] One has to admire them, that they, after all these mishaps, always would start anew.

55 W.H.C. Hellberg, Von den deutschen Siedlern im Kapland, Afrikanischen Heimatkalender, 1954.

56 H. Bruckschen, Aus der Heide in die Vlakte, in W. Blumer (red.), Pflanzgarten im Dünensand, p. 38 . 
Durch zähe, aufopfernde Arbeit gelang es nur mühsam, Schritt für Schritt Fuss zu fassen. ... Das Stückchen zugeteilte Land wurde käuflich erworben, eine Hütte aus Flechtwerk zur Unterkunft gebaut, und dann ging man daran, durch Sammeln von wildwachsenden Beeren das Geld für enige Hühner oder für Vieh zusammenzusparen ... Als der öde Boden dann das erste Gemüse hergab, da musste man dieses ... durch den weglosen Sand nach Kapstadt tragen. Die unsäglichen Mühen und Entbehrungen dieser ersten Siedler, die sich als einziges eine Schule und Kirche für die Erhaltung ihres kulturellen und kirchlichen Erbes ausbedungen hatten [which was not fulfilled, as the immigrants built their own school, and later the two churches at Philippi and in the Dunes], haben die Vlakte zu einem Schatzkästlein werden lassen. ${ }^{57}$

\section{The agricultural society}

The "Deutscher landwirtschaftlicher Verein" (German agricultural society) was founded on 12 September 1885 by Fritz Hörstmann, ${ }^{58}$ one of the immigrants of the Second Wave. The first official history of the community, encapsulated in the now iconic book Pflanzgarten im Dünensand, states it was the first agricultural society in South Africa as a whole. ${ }^{59}$ It has since been established that it was the second German agricultural society in South Africa. The first was founded in the Eastern Cape, also by German immigrants, but this one does not exist any more, which makes the Philippi society the oldest existing society.

One aim of the German agricultural society in Philippi was to act as a pressure group to implore the Cape Government to commit to some of the promises made in Germany during the recruitment. ${ }^{60}$

The society showed "überraschend schnell" (surprisingly soon), that they would be able to be successful if they stand together, because "Einigkeit" (unity) is strength.

57 Translation: Through hardy, sacrificial labour, they managed to settle, although step by step. The little piece of attributed land was bought, a small hut from lattices was built, and then they went about to save something for a couple of chickens or cattle by picking berries. ... When the barren soil then gave the first vegetables, they carried this through the roadless sand to Cape Town. The indescribable pains and hardships the first settlers suffered, who only negotiated for an own school and church for the preservation of their cultural and religious heritage [which was not fulfilled, as the immigrants built their own school, and later the two churches at Philippi and in the Dunes], managed to develop the Flats into a treasure trove.

58 Blumer, W.J. L. (ed), Pflanzgarten im Dünensand, 1959, p. 23.

59 Blumer, W.J. L. (ed), Pflanzgarten im Dünensand,,1959, p. 23.

60 W.H.C. Hellberg, Die Deutschen Evangelisch-Lutherischen Kirchengemeinden im Westen des Kaplands, p. 150. 
In fact, Hörstmann wrote in the German newspaper at the Cape, Das Capland,${ }^{61}$ that all Germans in South Africa should establish agricultural societies in order to form lobbies. It also shows that although these "Heidjer" did not have any formal higher academic education, they were well-informed. Hörstmann wrote:

Die in letzteren Zeit in Ihrem geschätzten Blatte erschienenen Artikel über Weinbau, Tabaksbau und andere landwirtschaftliche Fächer, haben sicher jedem strebsamen Farmer Freude gemacht. Auch wird wohl Niemand bezweifeln, dass durch Begründung landwirtschaftlicher Schulen, verbunden mit Versuchstationen, dem Lande in dierser Hinsicht ein grosser Vortheil erwächst. ${ }^{62}$

An annual publication, the Volkskalender, was meant, among others, to literally help the immigrants assimilate into their new environment, as it also gave advice on how, e.g., to adapt to the "new" Southern hemisphere seasons at the Cape. ${ }^{63}$ All of this contributed, together with the diligence of the first generations, to establish the Cape's "vegetable larder", as the area is generally referred to.

\section{Church and school}

Initially, the settlers were all members of the Lutheran St Johannis Church in Wynberg, on the edge of the Cape Flats, with the "Schulgemeinde" (school congregation) situated on "Wynberg Flats" at Philippi. ${ }^{64}$

For the devout Lutherans it was extremely important that their children should get a Lutheran education. Although they were of peasant stock, day labourers and artisans, it was important to them that their children were educated. Although all children had to work in the fields before and after school, it was imperative that they would not grow up as "barbarians". ${ }^{65}$ Education was regarded as a fundamental and important ally to ensure the survival of the German language, culture, traditions, and, importantly, religion.

\footnotetext{
61 Das Capland, 1885-09-25.

62 Translation: The articles on viticulture, tobacco growing and other agricultural activities that were published in your valued paper have probably been enjoyed by every ambitious farmer. Also, no one will doubt that the country will experience an immense benefit from the establishment of agricultural schools, in liaison with experimental farms.

63 G.W. Wagener, Volkskalender für Südafrika auf das Jahr 1888 (Hermann Michaelis, Cape Town, 1888), p 37.

64 L. Rabe, 'n Kultuurhistoriese studie van die Duitse nedersetting Philippi op die Kaapse Vlakte, 1994.

65 W.H.C. Hellberg, Duitse Immigrasie na Wes-Kaapland, 1959, p. 20.
} 
School was a means to an end: the child should learn enough German to be confirmed in its religion. ${ }^{66}$ This was also the case elsewhere in similar German immigrant communities in South Africa: ${ }^{67}$ A Lutheran religion education was far more important than an academic education.

It is interesting to note that even in 1959, the then consul-general of the German Federal Republic in Cape Town, Otto Heipertz, referred to the importance of education to the descendants of the immigrants, and that their children should be educated in the "Muttersprache" (mother tongue) in order to preserve their "Deutsche Art" (German nature). ${ }^{68}$

The fact that the school was of paramount importance to the immigrants was not a coincidence. This was one of the promises negotiated during the recruitment, and therefore one of the motivators to accept the immigration recruitment. However, as said, soon after their arrival the immigrants found that this was part of a whole range of empty promises - including the building of roads which would make the area more accessible. ${ }^{69}$ Within one year after the arrival of the last group in 1883 they themselves founded their own school, and the first school building was erected in $1886 .{ }^{70}$

This was met with antagonism from the Cape Colonial Government. They eventually erected a school adjacent to the German school with the intention of coaxing away children by offering free education. The German school, as a private and fee-paying school, had to be subsidised by the meagre income of the immigrants, which meant even more sacrifices to the first immigrants who already struggled to earn a living. ${ }^{71}$

To add to this, the Cape Government instituted a new school law in 1905 according to which the German school had to teach in English. According to various sources, the German community's patience "snapped". The community took the government to court and won. ${ }^{72}$

${ }^{66}$ W.H.C. Hellberg, “'n Terugblik” (Looking back”), in W.J.L. Blumer, Pflanzgarten im Dünensand, 1959 , p. 34.

67 U. Küsel, Die kulturele bydrae van die Hermannsburgse sendelinge/setlaars in Suid-Afrika ("The cultural contribution of the Hermannsburg missionaries/settlers in South Africa") (Pretoria, 1992), p. 55.

68 O.E. Heipertz, Zum, fünfundsiebzigjährigen Bestehen der Deutschen Schule Philippi-Vlake am Kap (congratulatory letter) in W.J.L. Blumer, Pflanzgarten im Dünensand, 1959, p. 7.

69 W.J.L. Blumer (ed.), Pflanzgarten im Dünensand, 1959; L. Rabe, 'n Kultuurhistoriese studie van die Duitse nedersetting Philippi op die Kaapse Vlakte, 1994.

70 W.J.L. Blumer (ed.), Pflanzgarten im Dünensand, 1959.

71 W.J.L. Blumer (ed.), Pflanzgarten im Dünensand, 1959, p. 29.

72 H. Bruckschen, Aus der Heide in die Vlakte, 1959, p. 40. 


\section{Cultural activities}

In a community where the official and unofficial motto was "Bete und Arbeite", or "Ora et Labora" (Pray and Work) as is the Latin wording on the gable of the German school building in Philippi, it is to be expected that its recreation centred around the church and other religio-cultural activities. There were also informal get-togethers, such as dances on Saturday nights, when it was "Feierabend" (time to relax), and the church bell was rung at 18:00 to mark the end of the work week. ${ }^{73}$

One settler, who was a small girl when her family arrived in 1883 , remembered in 1955 :

Oh, we had fun. Saturday nights we carried on through the sands or waded through the marshes to someone's small house where we danced on the clay floor to the tune of a harmonica or a hand organ until the early hours. And days after that when you milked a cow or turned the churn, those tunes still fluttered through one's head and kept you happy! $!^{74}$

According to this source, the German children also loved reading: they received books and magazines on a regular basis from Germany and sat at night by candle or oil lamp "happily whiling away the time".

Another source also remembers, besides the "German songs" and "German dances":

Entertainment there was enough, a lot of fun, and also enough books and German publications to read. ${ }^{75}$

It was predominantly religious reading matter, mostly from the Hermannsburg Mission, as well as books such as "Haus-Andachten", "Starck's Gebetbuch" and "Frisches Wasser". In addition, the congregation also collected money to start their own library. The first collection in 1901 raised the amount of $£ 11 / 10$, enough to buy the first 160 books for the library. ${ }^{76}$

According to another article, this "Erbe" (legacy) manifested itself also in various cultural organisations in the community, such as the founding of a "strong" youth group, a brass band, a gymnastics club and a choral society. ${ }^{77}$

73 Interview with F. Schultz, 1992.

74 A. Bouwer, Hul spore in die sand hul grootste monument ("Their footprints in the sand their greatest monument"), Sarie magazine, 1954-05-04, p. 16. Translated from Afrikaans.

75 A. Bouwer, Hul spore in die sand hul grootste monument, p. 16.

76 W.H.C. Hellberg, Die Deutschen Evangelisch-Lutherischen Kirchengemeinden, 1957, p. 206.

77 I. Steinhoff, Bauern aus der Lüneburger Heide am Kap der Guten Hoffnung, Hamburger Illustrierte, nr 6, 1938-02-07, p. 4. 
Because of the distances, the descendants eventually, towards the end of the nineteenth century, supported and maintained three congregations and three schools in the then still difficultly accessible Cape Flats. These congregations and schools were at Wynberg (the St Johannisgemeinde), Philippi (the Zionsgemeinde) and Neu Eisleben, the latter deeper into the so-called Dunes area. Still, the community functioned as a unit, bond together through background, hardship, language, religion and culture.

However, the British Colonial Government, after recruiting specifically Germans with certain characteristics to "tame" the Flats and to make it useful, in no unclear terms, "want[ed] to make [them] English" after their arrival. ${ }^{78}$

This, of course, especially taking into consideration the Hermannsburg/Harms influence in terms of their identity and cultural values, led to the already legendary hard-headed Germans to treasure their culture, language, religion and traditions even more. It is precisely this hard headedness, together with their characteristics of "Fleiss, Ausdauer, Ehrlichkeit und Sparsamkeit" (diligence, perseverance, honesty and thrift) ${ }^{79}$ which led the Cape Government to recruit Germans in the first place, which ensured their survival.

One can accept that the natural reaction would be for the Heidjer, arriving in a country where they did not understand the language, where they were maltreated and generally regarded as being inferior, to strengthen their impulse to remain "German".

This led to the fact that these immigrants, who sought a new future where they could be landowners instead of working for landowners, established a "lütje Dütschland" (little Germany, in the Lower German dialect of the immigrants). ${ }^{80}$

The "flax blonde German children" whom the German reporter described in the 1930s, who might as well have been playing on German village roads, but who have never been to Germany and whose grandparents have already been born in South Africa, ${ }^{81}$ still had a German identity, forged by a specific German-ness, even to the point of knowing Germanic mythology. ${ }^{82}$

One can concede that many things changed after the Second World War for the descendants of the German immigrants to Philippi. The first generation to marry from the 1950s onwards, consciously or subconsciously, married non-Lutheran, non-German Afrikaans- or English-speaking partners. ${ }^{83}$ This resulted in the first truly South African

\footnotetext{
W.J.L. Blumer (ed.), Pflanzgarten im Dünensand, 1959, p. 23.

Die ersten Anfänge in der Vlakte, in W.J.L. Blumer (ed), Pflanzgarten im Dünensand, 1959, p. 13.

Interview with I. Bode, b. Schultz, 1992.

I. Steinhoff, Bauern aus der Lüneburger Heide am Kap der Guten Hoffnung, 1938, p. 6.

Interview with F. Schultz, 1992.

W.J.L. Blumer (ed.), Pflanzgarten im Dünensand, 1959, p. 48.
} 
generation with its offspring having a "mixed" identity. In most cases, Afrikaans was the mother tongue, but a German identity was maintained through education, religious affiliation, family and community traditions. This generation, of whom this author is a member, and our border identity was described as "too Afrikaans for Friedrich Schiller, but too German for Jan Celliers [an Afrikaans poet]" ${ }^{84}$

In the 1970s the pastor of the Philippi congregation described the community as people whose fate it was to "live on the border", and that it was to be expected that they could not be that for those who expected a certain identity of them [the Germans], and, on the other hand, they were not yet that, which another group expected them to be [South Africans]. ${ }^{85}$

\section{South Africa in the $21^{\text {st }}$ century, the Bauernmission, British colonialism, German immigrants and the ironical twist of history}

The distinct German identity of the German immigrants to Philippi still resonated decades after the arrival of the last group of immigrants. Still, children were raised with the legendary work ethic of their forebears being instilled in them - together with the lore of how these forebears arrived at the Cape with nothing but their "two hands and their Lutheran Bible".

This was clear in 1933 with the golden jubilee celebration of the arrival of the last group of immigrants in 1833. A speaker reminded the audience of the German idiom "Halte was du hast, dass niemand deine Krone nehmet" (hold that which you have, in order not to lose your "crown"). The implication was that the community's crown would be their culture: their language, church and school. This was answered with "brausende Beifall" (loud cheering), after which the Deutschlandlied was sung. ${ }^{86}$

Leading up to these celebrations, and during the celebrations, especially men greeted one another with a sturdy handshake saying "50 Jahre harte Hände-Arbeit!" (the direct translation: "50 years of hard manual labour)", while the greeting was returned with "Treu Deutsch alle Wege! (Truly German, always!)" "87 This was regarded as a clarion call for descendants after the celebrations.

\footnotetext{
${ }^{84}$ H. Bodenstein, 1959, Unsere Schule einst und jetzt ("Our school then and now"), in W.J.L. Blumer (ed.), Pflanzgarten im Dünensand, 1959, p. 67.

85 L. Rabe, 'n Kultuurhistoriese studie van die Duitse nedersetting Philippi op die Kaapse Vlakte, 1994, p. 579 .

86 L. Rabe, 'n Kultuurhistoriese studie van die Duitse nedersetting Philippi op die Kaapse Vlakte, 1994, p. 512 .

87 Interviews with I. Bode, b. Schultz, \& F. Schultz, 1992.
} 
A report on the occasion in 1933 in a German newspaper ends with the hope that the German spirit will never wane, and that the "German" Flats will remain "a monument to German thrift, thoroughness and success". ${ }^{88}$

It is debatable how much longer the last surviving group on the shrinking agricultural area will be able to maintain the "monument" to German thrift and thoroughness. More than a century ago, Cape Town was too far away; today the proximity of Cape Town with its encroaching urbanisation, and other related factors, such as theft and crime, are detrimental to the survival of the area.

But whatever may happen, several "monuments", real and virtual, will be maintained. One such monument is the current usage of the Neu Eisleben church and school buildings.

A fitting "new life", and a fitting "coming together" of the legacy of the Bauernmission and consequently, German missionary colonialism, together with British colonialism, is the fact that this complex now houses a centre that intends to build "social capital" in the area.

The congregation of Neu-Eisleben, named after the birthplace of Martin Luther, ceased to exist and amalgamated with the Philippi congregation in the 1980s. Today, in an ironical twist of history, the buildings are used as a centre to serve HIV positive women and children in the sprawling townships that developed in this specific area since the 1960s as a result of the Apartheid government's influx control and work permit system for ethnic blacks from the Eastern Cape.

It is almost fitting, and poetic justice, that these new (im)migrants to the Western Cape, mainly of the isiXhosa ethnicity, are now the beneficiaries of this church building and the Lutheran charitable work that is being done on the premises of what used to be the Neu-Eisleben congregation.

The centre, called iThemba Labantu ${ }^{89}$, isiXhosa for "Hope for the People" and run by the Lutheran Community Centre, is housed in the church and its surrounding buildings, and provides various social services, including a soup kitchen and work opportunities for women with HIV/Aids.

\section{In conclusion}

The legacy of the German "Bauernmission", together with that of colonialism and how it perpetuated European German and British hegemonic supremacy, still needs much more research and interrogation.

\footnotetext{
88 Der Deutsch-Afrikaner, 1933-02-09, n.p.

89 http://www.themba-labantu.co.za/
} 
To try and gain an understanding of the forging of new communities and cultures as a result of the Völkerewanderung, the Bauernmission and its colonialism, in conjunction with the specific colonialism of the British Empire at the Cape of Good Hope, much more critical analysis and reflection is needed.

Still, it might be fitting to end off with a "Hausspruch"90 which typically represents the faith, but also hope and general take on life of the Heidjer at the Cape of Good Hope. One can also say that this "Spruch" infuses the work that is now conducted in the Neu Eisleben church building which now serves as iThemba Labantu. It reads as follows, with the English text next to it:

Wo Glaube
Da Liebe
Wo Liebe
Da Friede
Wo Friede
Da Segen
Wo Segen
Da Gott
Wo Gott - keine Noth! ${ }^{91}$

Where there is Belief

There is Love

Where there is Love

There is Peace

Where there is Peace

There is Blessing

Where there is Blessing

There is God

Where God is, there will be no distress!

90 Essential part of any interior decorating in a Philippi German immigrant home; several examples can be seen in the Philippi Settler Museum.

91 This "Haussegen", to be seen in the German Settler Museum, belonged to the Peck Family, who were part of the Third Wave's 1883 immigrants. Donated by Ilse Ellmann, born Freiboth, a grandchild of the Pecks. 